\section{The Effect of Physical and Hydraulic Properties of Peatmoss and Pumice on Douglas Fir Bark Based Soilless Substrates}

\author{
Magdalena Zazirska Gabriel ${ }^{1}$ \\ Department of Crop and Soil Science, 3017 Agricultural and Life Science \\ Building, Oregon State University, Corvallis, OR 97331
}

James E. Altland ${ }^{2}$

USDA-ARS, Application Technology Research Unit, Ohio Agricultural Research and Development Center, 1680 Madison Avenue, Wooster, OH 44691

\author{
James S. Owen, Jr. \\ North Willamette Research and Extension Center, Oregon State University, \\ 15210 NE Miley Road, Aurora, OR 97002
}

Additional index words. moisture characteristic curves, container capacity, air space, particle size distribution, available water, water-buffering capacity

\begin{abstract}
Douglas fir [Pseudotsuga menziesii Mirb. (Franco)] bark (DFB), sphagnum peatmoss, and pumice are the most common substrate components used in the Oregon nursery industry. The objective of this study was to document the effect of peat and pumice addition on the physical and hydrological properties of DFB soilless substrates. A secondary objective was to determine if measured properties of mixed soilless substrates can be accurately predicted from the known properties of the individual components. Treatment design was a $3 \times 3$ factorial with three rates each of sphagnum peatmoss and pumice $(0 \%, 15 \%$, and $30 \%$ by vol.) added to DFB. The resulting nine substrates were measured for total porosity, air space, container capacity, and bulk density using porometers. Moisture characteristic curves were generated by measuring water content along a continuous column. Adding pumice to DFB decreased total porosity, container capacity, available water, and water-buffering capacity but increased bulk density. Adding peatmoss to DFB increased total porosity, container capacity, and available water but decreased air space and bulk density. Comparison of predicted values against measured values indicated that bulk density could be predicted reliably; however, all other physical properties could not be accurately predicted.
\end{abstract}

Nursery producers create their own substrates by mixing two or more components. Components are often regional and based on available resources local to the nursery operation. Outdoor container nurseries use bark as the primary component mixed with one or more other materials to create an infinite number of possible substrates. Yeager and Newton (2001) reported that at a hands-on workshop in Hillsborough County, FL, nurseries brought 40 soilless substrates used for containerized nursery production for analysis during the workshop. Twenty-six of these

Received for publication 11 July 2008. Accepted for publication 20 Sept. 2008.

Research supported by funding appropriated to the North Willamette Research and Extension Center, Oregon State University, Aurora, OR.

We gratefully acknowledge Marta Mielcarek for laboratory assistance and Maria Dragila and James Cassidy for technical assistance.

${ }^{1}$ Graduate Research Assistant.

${ }^{2}$ To whom reprint requests should be addressed; e-mail James.Altland@ARS.USDA.GOV. found excellent agreement between measured and predicted physical properties using an additive model:

$$
\begin{aligned}
& \{\text { Mixtureproperty }= \\
& \qquad \sum_{i=1}^{n}\left(\text { component volume ratio }_{\mathrm{i}}\right) \\
& \quad \times\left({\text { component } \left.\left.\text { property }_{\mathrm{i}}\right)\right\}}\right.
\end{aligned}
$$

for combinations of bark, peat, sawdust, and poppy straw amended with either sand or scoria. However, this study was limited to equal ratios of just two materials for any given substrate. Comparable component ratios are rare in containerized nursery crop production.

Jenkins and Jarrell (1989) attempted to validate Eq. [1]. They found that linear relationships between measured and predicted properties of bark:sand and bark:perlite substrates were good for bulk density $\left(\mathrm{D}_{\mathrm{b}}\right)$ but mixed or poor for other parameters such as total porosity (TP), air space (AS), and container capacity (CC).

The most common substrate components use in the Oregon nursery industry is douglas fir [Pseudotsuga menziesii Mirb. (Franco)] bark (DFB), sphagnum peatmoss, and pumice. Each of these individual components has been studied. Buamscha et al. (2007) evaluated physical and chemical properties of fresh and aged DFB and reported that aged DFB had lower AS and higher CC compared with fresh DFB. These results were similar to findings reported by Bilderback et al. (2005) that aged pine bark increases $\mathrm{CC}$ and decreases AS compared with fresh pine bark. Puustjarvi and Robertson (1975) provide a thorough review of the properties of peatmoss. They state that one of the most important properties of peat is its capacity to absorb and internally retain large quantities of water. The amount of water held by a given weight of peat can be 15 to 20 times its own weight depending on peat type. Pumice is a porous igneous rock found primarily in volcanic regions of the world such as the Cascade Mountain Range in Oregon. The impact of pumice on crop growth and container physical properties has been studied throughout the world, because pumice from each volcanic region has unique properties (Gizas and Savvas, 2007; Gunnlaugsson and Adalsteinsson, 1995; Lenzi et al., 2001). Buamscha and Altland (2005) documented the physical properties of pumice used for containerized nursery production. Pumice is usually added to bark or peat substrates to hypothetically increase aeration, porosity, and drainage; however, there are no or little data to support this hypothesis.

As a result of widespread use of peat and pumice as an amendment for DFB in the Oregon nursery industry, the objective of our research was to document the effect of these components on the physical and hydrological properties of DFB substrates. A secondary goal was to determine if prediction algorithms such as those proposed by Jenkins and Jarrell 
(1989) can accurately predict physical properties of DFB, peat, and pumice mixes.

\section{Materials and Methods}

General procedures. Aged DFB [screened to $0.9 \mathrm{~cm}(0.4 \mathrm{in})$ ] was collected from stockpiles intended for nursery container production (Marr Bros., Monmouth, OR). Pumice (less than $9.5 \mathrm{~mm}$ ) (Pro-Gro, Sherwood, OR) and Canadian sphagnum peat (Sun Gro Horticulture Canada Ltd., Laval, Quebec, Canada) were used as the components to make nine substrates. Physical properties of the components before mixing are provided (Table 1). Approximately $0.11 \mathrm{~m}^{3}$ of each substrate was prepared by mixing components with a shovel on a nonporous concrete floor. Substrates were stored individually in plastic containers in a dark, cool shed until needed for analysis.

Substrate physical properties. DFB samples were adjusted to $1.5 \mathrm{~g} \cdot \mathrm{g}^{-1}$ mass wetness and packed in $347-\mathrm{cm}^{3}$ aluminum cores $(7.6$ $\mathrm{cm}$ tall $\times 7.6 \mathrm{~cm}$ i.d.) according to methods described by Fonteno and Bilderback (1993). There were three replications for each substrate. Aluminum cores were attached to North Carolina State University Porometers $^{\mathrm{TM}}$ (Horticultural Substrates Laboratory, North Carolina State University, Raleigh, NC) for determination of AS. Cores were weighed, oven-dried for $4 \mathrm{~d}$ at $60{ }^{\circ} \mathrm{C}$, and weighed again to determine CC. Total porosity was calculated as the sum of AS and CC. All physical properties (TP, AS, CC) were calculated as the algebraic mean of the core. Bulk density was determined using oven-dried $\left(60{ }^{\circ} \mathrm{C}\right)$ substrate in $347-\mathrm{cm}^{3}$ cores. Unavailable water (UAW), held in the substrate at $1.5 \mathrm{MPa}$ or greater, was determined with $174-\mathrm{cm}^{3}$ cores $(3.3 \mathrm{~cm}$ tall $\times$ $7.6 \mathrm{~cm}$ i.d.) using a porous ceramic pressure plate extractor by a procedure developed by Milks et al. (1989). Available water (AW) is the water determined by subtracting UAW

Table 1. Particle size distribution and physical properties of douglas fir bark (DFB), peat, and pumice $(\mathrm{n}=3)$ before mixing.

\begin{tabular}{lcccr}
\hline $\begin{array}{l}\text { Particle size } \\
\text { distribution }\end{array}$ & $\begin{array}{c}\text { Sieve size } \\
(\mathrm{mm})\end{array}$ & DFB & Peat & Pumice \\
\cline { 2 - 5 } Coarse & 19.00 & 0.00 & 0.00 & 0.00 \\
& 12.50 & 0.00 & 2.13 & 0.00 \\
& 6.30 & 0.26 & 8.85 & 8.13 \\
& 4.00 & 8.45 & 7.94 & 14.63 \\
& 2.80 & 13.19 & 5.80 & 12.22 \\
Medium & 2.00 & 13.33 & 5.00 & 10.03 \\
& 1.40 & 12.34 & 4.72 & 7.57 \\
& 1.00 & 10.47 & 6.13 & 5.24 \\
Fine & 0.71 & 8.91 & 7.64 & 3.60 \\
& 0.50 & 9.48 & 8.68 & 3.12 \\
& 0.35 & 7.63 & 10.64 & 2.11 \\
& 0.25 & 6.57 & 9.18 & 2.13 \\
Total porosity $(\%)$ & 0.18 & 4.59 & 6.85 & 11.25 \\
Air space $(\%)$ & 0.11 & 2.99 & 7.94 & 77 \\
Container capacity $(\%)$ & Pan & 2.01 & 6.59 & 39 \\
Bulk density $\left(\mathrm{g} \cdot \mathrm{cm}^{-3}\right)$ & & 87 & 91 & 38 \\
\hline
\end{tabular}

from CC. Particle size distribution of DFB, pumice, and peat using $\approx 100 \mathrm{~cm}^{3}$ oven-dried substrate $\left(60^{\circ} \mathrm{C}\right)$ was determined using 19.0, $12.5,6.30,4.0,2.8,2.0,1.4,1.0,0.71,0.50$, $0.35,0.25,0.18$, and $0.11 \mathrm{~mm}$ soil sieves. Particles $0.11 \mathrm{~mm}$ or less were collected in a with a RX-29/30 Ro-Tap ${ }^{\circledR}$ test sieve shaker (278 oscillations/min, 150 taps/min) (W.S. Tyler, Mentor, $\mathrm{OH}$ ).

Moisture characteristic curves. Columns $(112 \mathrm{~cm}$ tall $\times 7.6 \mathrm{~cm}$ i.d. $)$ were cut from schedule 40 polyvinyl chloride (PVC) rigid pipe. Columns were extended for packing by adding $30-\mathrm{cm}$ long sections of schedule 40 $\mathrm{PVC}$ rigid pipe to both ends of the $112-\mathrm{cm}$ pipe using clear packing tape. Columns were hand packed. Substrate was constantly settled while packing by tapping on the column wall at $100 \mathrm{taps} / \mathrm{min}$ with a schedule $40 \mathrm{PVC}$ rigid pipe $(61 \mathrm{~cm}$ long $\times 1.3 \mathrm{~cm}$ i.d.). After filling the extended column, the $30-\mathrm{cm}$ PVC pipe extension at the top of the column was removed. A PVC base was placed on the column using a rubber coupling $(8.6 \mathrm{~cm}$ i.d. $)$ and fastened with hose clamps (Fernco, Inc. Davison, MI). The base contained a rigid mesh screen to ensure the substrate remained stable in the column. To ensure uniform $D_{b}$, columns were inverted and the length of the column was tapped. The second $30-\mathrm{cm}$ long extension was removed. A $9.5-\mathrm{cm}$ wide petri dish was used to cover the top of the column to prevent evaporation. Columns were bottom-saturated with water for $4 \mathrm{~h}$ or longer, then remained saturated for $8 \mathrm{~h}$ or longer, and allowed to drain to $\approx 6 \mathrm{~cm}$ above the base of the column $\left(\mathrm{Z}_{0}\right)$ for $4 \mathrm{~h}$ or longer. Columns were placed in a freezer at $-21^{\circ} \mathrm{C}$ for $2 \mathrm{~d}$ or longer. Frozen cores were cut into 10 sections $(\approx 10 \mathrm{~cm}$ tall) starting $\approx 6 \mathrm{~cm}$ above the base of the column at $\mathrm{Z}_{0}$. Columns were cut using a Jet horizontal bandsaw (Jet, Rockford, IL) with a $0.9-\mathrm{mm}$ thick saw blade. Actual height of cut sections was determined by measuring height at four points along the circumference; pan. Sieves and pan were shaken for $3 \mathrm{~min}$ volume was calculated for each section separately using its averaged height. Each cut section was weighed, oven-dried at $60^{\circ} \mathrm{C}$ for $3 \mathrm{~d}$, and weighed again to determine water content $\left(\mathrm{cm}^{3} \cdot \mathrm{cm}^{-3}\right)$. From moisture characteristic curve (MCC), easily available water (EAW) was calculated as the percent of available water between 10 and $50 \mathrm{~cm}$ suction $\left(\mathrm{H}_{2} \mathrm{O}\right)\left(\mathrm{EAW}=\Theta_{50}-\Theta_{10}\right)$, whereas water-buffering capacity $\left(\Theta_{100}-\Theta_{50}\right)$ was calculated as percent water available between 50 and $100 \mathrm{~cm}$ suction (de Boodt and Verdonck, 1972).

Physical properties were subjected to univariate and multivariate analysis of variance. Moisture characteristic curves were fit with a four-parameter sigmoid curve (Table 2). Curves for each substrate were compared with each other using the lack of fit test. All statistical analyses were conducted with SAS 9.1 (SAS Institute, Cary, NC), although figures were constructed with SigmaPlot 10.0 (Systat Software, Inc., San Jose, CA).

\section{Results and Discussion}

Physical properties. Multivariate analysis shows that peat and pumice interacted to affect physical properties (TP, AS, and CC) of DFB substrates (Table 3). Total porosity was affected by peatmoss and pumice; however, there was no interaction $(P=0.25)$ Averaging across levels of pumice, TP increased from $85 \%$ to $89 \%$ as the level of peatmoss increased from $0 \%$ to $30 \%$. Conversely, TP decreased from $89 \%$ to $85 \%$ with increasing level of pumice. Both CC and AS were affected by the interaction of peatmoss and pumice. Within a given level of peatmoss, adding pumice caused a decrease in $\mathrm{CC}$ (with the exception of the substrate containing $15 \%$ pumice and $30 \%$ peat), whereas measured values of AS were erratic. Within each level of pumice, adding peatmoss caused an increase in $\mathrm{CC}$ and decrease in AS. Unavailable water was affected by peat and pumice but not their interaction (Table 4). Averaging across levels of pumice, adding peatmoss caused a decrease in UAW and thus an increase in AW. Conversely, adding pumice caused an increase in UAW at the highest amendment rate. Lowder et al. (2006) reported the changes in physical properties of pine bark by amending with $10 \%$ or $20 \%$ sand which, in general, contradicts our findings. They reported that increasing levels of sand increased CC and AW. Sand and pumice are often thought to be analogous potting materials in that they are both inorganic and dense components. However, the two materials have drastically different properties. Although sand and pumice can vary by source, Pokorny et al. (1986) reported sand to have $\mathrm{D}_{\mathrm{b}}$ of $1.6 \mathrm{~g} \cdot \mathrm{cm}^{-3}$ with $27 \%$ by weight and to have a particle size less than $0.42 \mathrm{~mm}$. In contrast, pumice has $D_{b}$ of $0.41 \mathrm{~g} \cdot \mathrm{cm}^{3}$ with only $17 \%$ by weight having a particle size less than $0.35 \mathrm{~mm}$ (Table 1). Differences in $\mathrm{D}_{\mathrm{b}}$ and fine particles may explain the different responses of bark to sand and pumice. 
Table 2. Parameters estimates (with SEs in parentheses) for moisture characteristic curves of nine douglas fir bark substrates amended with peatmoss or pumice. ${ }^{2}$

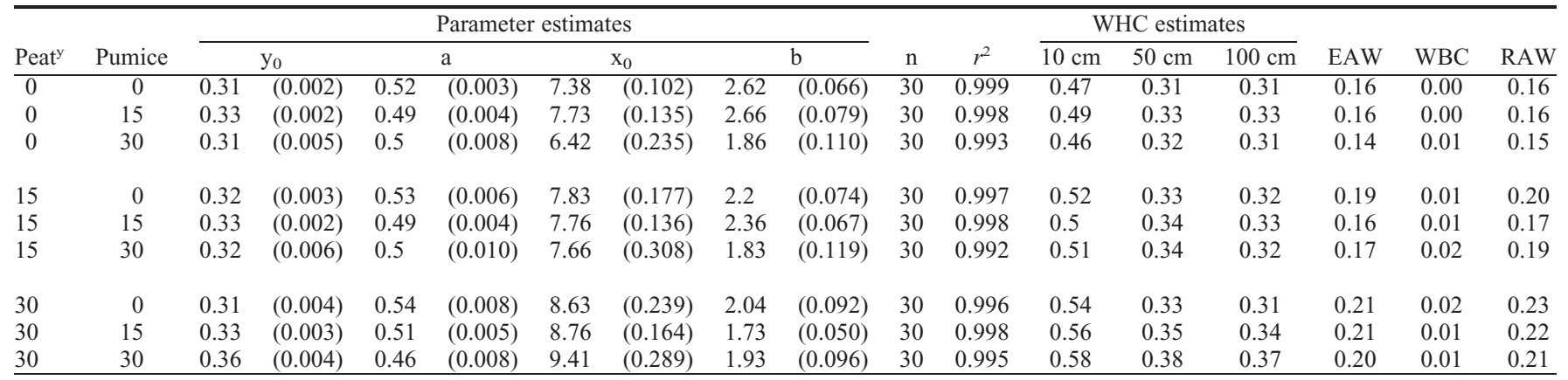

${ }^{\mathrm{z}}$ See Figures $1 \mathrm{~A}-\mathrm{C}$ and $2 \mathrm{~A}-\mathrm{C}$.

${ }^{\mathrm{y}}$ Parameters were estimated for the sigmoid function $\mathrm{y}=\mathrm{y}_{0}+\left\{\mathrm{a} /\left[1+\left(\mathrm{x} / \mathrm{x}_{0}\right)^{\mathrm{b}}\right]\right\}$.

$\mathrm{WHC}=$ water holding capacity; $\mathrm{EAW}=$ easily available water or that which is available between 10 and $50 \mathrm{kPa}$; WBC $=$ water-buffering capacity or that which is available between 50 and $100 \mathrm{kPa}$; RAW = readily available water or that which is available between 10 and $100 \mathrm{kPa}$.

Table 3. Physical properties of douglas fir bark (DFB) affected by incremental additions of peatmoss and pumice.

\begin{tabular}{|c|c|c|c|c|c|c|c|}
\hline & & $\mathrm{TP}^{\mathrm{y}}$ & AS & $\mathrm{CC}$ & UAW & AW & \multirow[b]{2}{*}{$\mathrm{D}_{\mathrm{b}}\left(\mathrm{g} \cdot \mathrm{cm}^{-3}\right)$} \\
\hline $\mathrm{Peat}^{2}$ & Pumice & \multicolumn{5}{|c|}{ 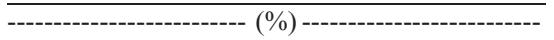 } & \\
\hline 0 & 0 & 87 & 28 & 60 & 23 & 37 & 0.16 \\
\hline 0 & 15 & 86 & 29 & 57 & 23 & 34 & 0.22 \\
\hline 0 & 30 & 82 & 28 & 54 & 25 & 29 & 0.27 \\
\hline 15 & 0 & 88 & 24 & 64 & 22 & 42 & 0.15 \\
\hline 15 & 15 & 87 & 26 & 61 & 21 & 40 & 0.20 \\
\hline 15 & 30 & 86 & 27 & 59 & 24 & 35 & 0.25 \\
\hline 30 & 0 & 92 & 29 & 64 & 21 & 43 & 0.14 \\
\hline 30 & 15 & 88 & 19 & 69 & 22 & 47 & 0.18 \\
\hline 30 & 30 & 87 & 25 & 62 & 22 & 40 & 0.24 \\
\hline $\begin{array}{l}\text { Tukey's least significant } \\
\text { difference }(0.05)\end{array}$ & & 5 & 8 & 6 & 2 & & 0.01 \\
\hline Univariate main effects & & \multicolumn{6}{|c|}{$\operatorname{Pr}>F$} \\
\hline Peat & & 0.0003 & 0.0930 & $<0.0001$ & 0.0002 & & $<0.0001$ \\
\hline Pumice & & 0.0010 & 0.0055 & 0.0001 & 0.0001 & & $<0.0001$ \\
\hline Interaction & & 0.2466 & 0.0082 & 0.0030 & 0.2205 & & 0.0067 \\
\hline Multivariate main effects & & & $\operatorname{Pr}>F$ & & & & \\
\hline Peat & & & 0.0001 & & & & \\
\hline Pumice & & & 0.0001 & & & & \\
\hline Interaction & & & 0.0104 & & & & \\
\hline
\end{tabular}

${ }^{2}$ Peat and pumice were added at $0 \%, 15 \%$, or $30 \%$, by volume, to DFB.

${ }^{\mathrm{T}} \mathrm{TP}, \mathrm{CC}, \mathrm{AS}, \mathrm{UAW}$, and $\mathrm{D}_{\mathrm{b}}$ represent total porosity, container capacity, air space, unavailable water, and bulk density, respectively.

Table 4. Linear relationship between predicted and measured physical properties of nine substrates comprised of douglas fir bark (DFB), peatmoss, and pumice.

\begin{tabular}{lcc}
\hline Properties & \multicolumn{1}{c}{ Equation } & $r^{2}$ \\
\hline Bulk density & $\mathrm{y}=0.75 \mathrm{x}+0.03$ & 0.99 \\
Total porosity & $\mathrm{y}=0.23 \mathrm{x}+65.75$ & 0.30 \\
Air space & $\mathrm{y}=0.08 \mathrm{x}+26.58$ & 0.06 \\
Container capacity & $\mathrm{y}=0.38 \mathrm{x}+34.64$ & 0.37 \\
\hline
\end{tabular}

The effect that peatmoss and pumice have on the substrate TP, AS, CC, and UAW is probably related to particle size of the amendments. Although the distribution of pumice is skewed heavily toward coarse particles, over $11 \%$ were less than $0.11 \mathrm{~mm}$ compared with DFB that contained just $2 \%$ of those sized particles (Table 1). Fine pumice particles will settle between the larger pores of DFB substrate, thus causing a decrease in TP. Container capacity also decreased, likely because pumice is inorganic and retains little water. Particle size distribution of peatmoss is more uniformly distributed across the range of measured sizes than pumice, but also with a greater amount of fine particles than DFB. Although fine peatmoss particles would have settled between DFB particles, similar to pumice, peatmoss can hold up to 20 times its weight in water (Puustjarvi and Robertson, 1975). Thus, adding peatmoss increased CC and decreased AS with the net effect of increasing TP.

Bulk density was affected by an interaction between peatmoss and pumice. Within a given level of peatmoss, adding pumice increased $D_{b}$ of the substrate; within a level of pumice, peatmoss caused a decrease in $\mathrm{D}_{\mathrm{b}}$. Bulk density of DFB alone is $0.16 \mathrm{~g} \cdot \mathrm{cm}^{-3}$, whereas that for peatmoss and pumice is 0.07 and $0.41 \mathrm{~g} \cdot \mathrm{cm}^{-3}$, respectively (Table $3)$. Substituting a part of a DFB substrate with less dense peatmoss lowered $D_{b}$, whereas amending with the denser pumice increased $\mathrm{D}_{\mathrm{b}}$.

Predicted values for physical properties. An attempt was made to predict the physical properties of the nine substrate mixes using only the known physical properties of the
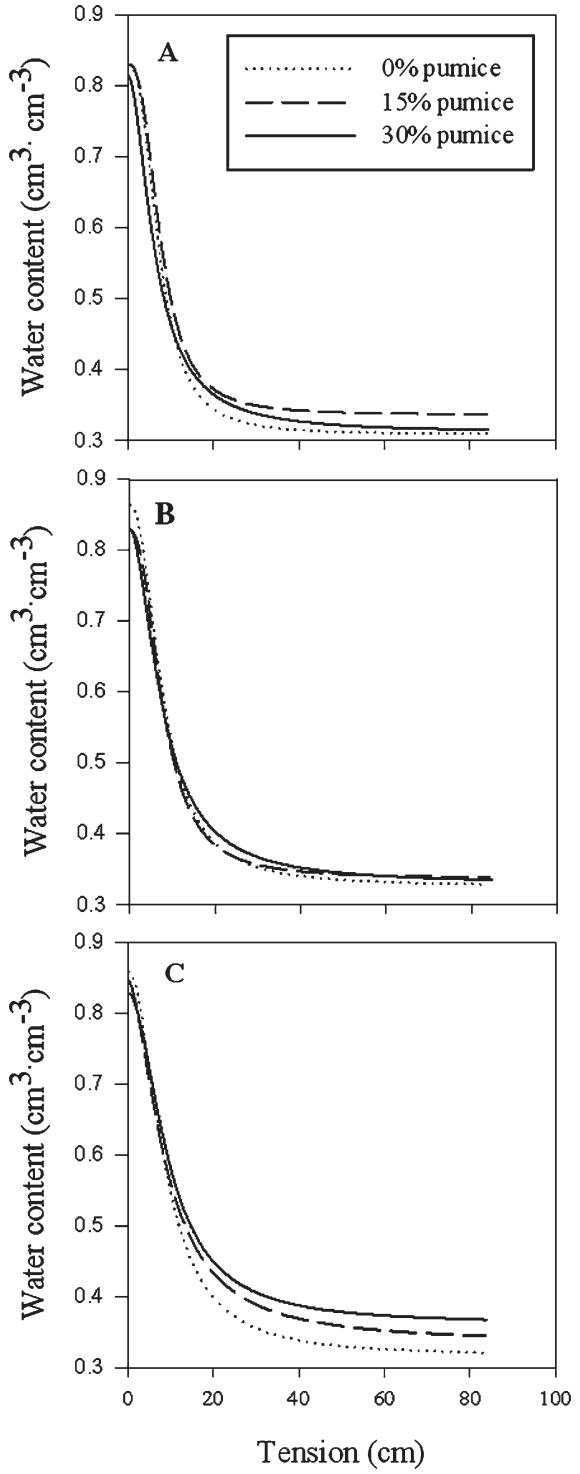

Fig. 1. Moisture characteristic curves of substrates containing (A) $0 \%$, (B) $15 \%$, and (C) $30 \%$ peatmoss amended with varying levels of pumice (see Table 2 for predicted equations).

components (Table 1) and the equation provided by Jenkins and Jarrell (1989). A linear relationship was fit to measured and predicted physical properties of the nine 
substrates (Table 4). If two different procedures for estimating substrate physical properties (measured and predicted) were to provide the same results, their relationship could be described by a straight line with slope $(\mathrm{m})=1, y$-intercept $(\mathrm{b})=0$, and $r^{2}$ approaching 1.0. The equation by Jenkins and Jarrell (1989) was effective in predicting $\mathrm{D}_{\mathrm{b}}\left(\mathrm{m}=0.76, \mathrm{~b}=0.03\right.$, and $\left.r^{2}=0.99\right)$. The slope of the line relating measured and predicted $\mathrm{D}_{\mathrm{b}}$ is less than 1 , meaning the prediction equation would tend to underestimate $\mathrm{D}_{\mathrm{b}}$ slightly. Pokorny et al. (1986) also reported that an additive model underestimates $\mathrm{D}_{\mathrm{b}}$ of pine bark and sand substrates. They attributed underestimation to shrinkage that occurs when two components of disparate particle sizes are mixed. The equation for TP, AS, and CC each had slopes far from 1, b far from 0 , and low $r^{2}$ values (Table 4). Linear relationships for TP, AS, and $\mathrm{CC}$ were poor,
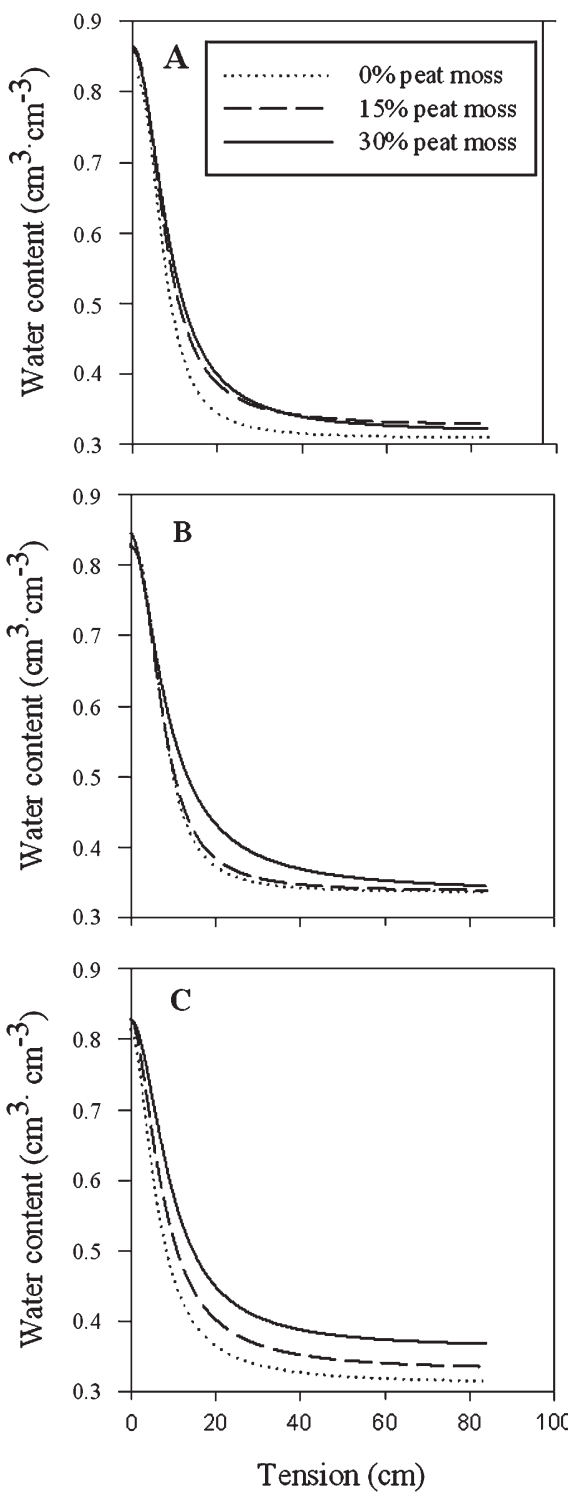

Fig. 2. Moisture characteristic curves of substrates containing (A) $0 \%$, (B) $15 \%$, and (C) $30 \%$ pumice amended with varying levels of peatmoss (see Table 2 for predicted equations). and scatterplots of the data (not presented) clearly demonstrated that no other linear or nonlinear relationship would provide a better explanatory equation.

Moisture characteristic curves. Moisture characteristic curves relate the availability of water in a given substrate over a range of tensions. The influence of peat within a given level of pumice on MCCs is provided in Figure $1 \mathrm{~A}-\mathrm{C}$, and likewise the influence of pumice on $\mathrm{MCC}$ within a given level of peat is provided in Figure 2A-B. The parameters of estimates for each curve are in Table 2 . The lack of fit test was used to compare all curves resulting in 36 unique comparisons in which all curves were found to be different from each other $(P<0.01$, data not presented).

The parameter $y_{0}$ represents the point on the $y$-axis at which the curve flattens to a minimum, which is the level of water $\left(\mathrm{cm} \cdot \mathrm{cm}^{-1}\right)$ that is retained in substrates at high tension. The sum of parameters $y_{0}+a$ estimate water content when tension is zero (complete saturation) and should be equivalent to TP (Table 3). Comparing $y_{0}+a$ offers slightly different values than TP measured by porometers (Table 3), although the trends with respect to peat and pumice are similar. Differences between porometer TP and column estimation with $y_{0}+a$ are likely the result of differences in $D_{b}$ from variation in packing procedures. The parameter $b$ is the tension at which water content declines from the maximum, whereas $x_{0}$ is the tension at which the sigmoid curve changes from convex to concave (inflection point). The parameter $b$ decreases slightly with increasing peat and pumice, although differences are minor. The parameter $x_{0}$ is the most important parameter in how it shapes the MCC. As $x_{0}$ increases, the inflection point moves to the right, which results in the higher value of water content at $10 \mathrm{~cm}$ tension. This in turn results in higher calculated values for EAW. Parameter $x_{0}$ increases with increasing peatmoss but changes relatively little with increasing pumice. As a result of differing MCC (Table 2), EAW remained constant or decreased slightly with increasing pumice level. Averaging across levels of peat, EAW was $0.19,0.18$, and $0.17 \mathrm{~cm} \cdot \mathrm{cm}^{-1}$ with pumice at $0 \%, 15 \%$, and $30 \%$, respectively. Conversely, adding peat caused an increase in EAW and readily available water both within and across levels of pumice. Waterbuffering capacity is much less than EAW but followed the same trend as EAW with respect to its response to peat and pumice.

In summary, this research demonstrates three important characteristics of DFB-based substrates: 1) peatmoss and pumice affect physical properties of DFB substrates; 2) there is often an interaction between peatmoss and pumice regarding their effects on substrate physical properties; and 3) substrate physical properties discussed here, with the exception of $\mathrm{D}_{\mathrm{b}}$, cannot be accurately predicted from the known properties of the components using Eq. [1]. Fonteno (1996) stated that when components are blended, the chemical and physical properties of the com- ponents are married to form new properties that are different from the individual components. This is a more realistic perspective on substrate mixes than the notion that physical properties of substrate mixes could be predicted with a mathematical model. Despite our inability to accurately predict most substrate physical properties, this research demonstrates that peatmoss generally increases TP, CC, AS, and EAW while decreasing $\mathrm{D}_{\mathrm{b}}$ and UAW. Furthermore, pumice generally decreases TP, CC, and EAW while causing an increase in $D_{b}$.

This research does not suggest one amendment is superior to the other or that the resulting properties of any of the nine substrates are more conducive to plant growth Lowder et al. (2006) grew hellebores (Helleborus $\times$ hybridus and $H$. foetidus) in pine bark amended with different rates of sand or peatmoss and demonstrated that hellebores are best grown in substrates with high AW and low AS. Conversely, Breedlove et al. (1999) grew 'Hershey Red' azalea (Rhododendron sp.) in pine bark alone or pine bark amended with peatmoss or perlite and showed that greatest growth and quality occurred in $100 \%$ pine bark, which, among all substrates, had the highest AS and lowest AW. No single substrate is universally suitable to all plant species (Lea-Cox and Smith, 1997). Plants will respond more favorably to substrates that best mimic conditions of their natural habitats. The usefulness of this research is to demonstrate how DFB substrates respond to the most common amendments used along the west coast of the United States. Nursery growers can use this to make better decisions about peatmoss and pumice amendment rates and how they might interact with production or irrigation regimes.

\section{Literature Cited}

Beardsell, D.V., D.G. Nicholas, and D.L. Jones. 1979. Physical properties of nursery pottingmixtures. Scientia Hort. 11:1-8.

Bilderback, T.E., S.L. Warren, J.S. Owen, and J.P Albano. 2005. Healthy substrates need physicals too! HortTechnology 15:747-751.

Blythe, E.K. and D.J. Merhaut. 2007. Grouping and comparison of container substrates based on physical properties using exploratory multivariance statistical methods. HortScience 42:353363.

Breedlove, D., L. Ivy, and T. Bilderback. 1999. Comparing potting substrates for growing 'Hershey Red' azaleas. Proc. Southern Nurs. Assoc. Res. Conf. 44:71-75.

Buamscha, G.M. and J. Altland. 2005. Pumice and the Oregon nursery industry. Digger 49:18-27.

Buamscha, G.M., J.E. Altland, D.M. Sullivan, D.A. Horneck, and J. Cassidy. 2007. Chemical and physical properties of douglas fir bark relevant to the production of containers plants. HortScience 42:1281-1286.

de Boodt, M. and O. Verdonck. 1972. The physical properties of the substrates in horticulture. Acta Hort. 26:37-44.

Fonteno, W.C. 1996. Growing media: Types and physical/chemical properties, p. 93-122. In: Reed, D.W. (ed.). Water, media, and nutrition 
for greenhouse crops. Ball Publishing, Batavia, IL.

Fonteno, W.C. and T.E. Bilderback. 1993. Impact of hydrogel on physical properties of coarsestructured horticultural substrates. J. Amer. Soc. Hort. Sci. 118:217-222.

Gizas, G. and D. Savvas. 2007. Particle size and hydraulic properties of pumice affect growth and yield of greenhouse crops in soilless culture. HortScience 42:1274-1280.

Gunnlaugsson, B. and S. Adalsteinsson. 1995. Pumice as environment-friendly substrate- $\mathrm{A}$ comparison with rockwool. Acta Hort. 401: 131-136.

Jenkins, J.R. and W.M. Jarrell. 1989. Predicting physical and chemical properties of container mixtures. HortScience 24:292-295.

Lea-Cox, J.D. and I.E. Smith. 1997. The interaction of air-filled porosity and irrigation regime on the growth of three woody perennial (citrus) species in pine bark substrates. Proc. Southern Nurs. Assoc. Res. Conf. 42:169174.

Lenzi, A., N. Oggiano, M. Maletta, A. Bolaffi, and R. Tesi. 2001. Physical and chemical characteristics of substrates made of perlite, pumice and peat. Italus Hortus 8:23-31.

Lowder, A.W., H.T. Kraus, S.L. Warren, and A. Prehn. 2006. Nursery production of Helleborus sp.: Substrate irrigation. Proc. Southern Nurs. Assoc. Res. Conf. 51:36-39.

Milks, R.R., W.C. Fonteno, and R.A. Larson. 1989. Hydrology of horticultural substrates: II. Predicting physical properties of media in containers. J. Amer. Soc. Hort. Sci. 114:53-56.

Ownley, B.H., D.M. Benson, and T.E. Bilderback. 1990. Physical properties of container media and relation to severity of phytophtora root rot of Rhododendron. J. Amer. Soc. Hort. Sci. 115: 564-570.

Pokorny, F.A., P.G. Gibson, and M.G. Dunavent. 1986. Prediction of bulk density of pine bark and/or sand potting media from laboratory analyses of individual components. J. Amer. Soc. Hort. Sci. 111:8-11.

Puustjarvi, V. and R.A. Robertson. 1975. Physical and chemical properties, p. 23-38. In: Robinson, D.W. and J.G.D. Lamb (eds.). Peat in horticulture. Academic Press, London, UK.

Tilt, K.M. and T.E. Bilderback. 1987. Physical properties of propagation media and their effects on rooting of three woody ornamentals. HortScience 22:245-247.

Yeager, T. and R. Newton. 2001. Physical properties of substrates evaluated during educational programs in Hillsborough County, Florida. Proc. Southern Nurs. Assoc. Res. Conf. 46:74-77. 